\title{
Biological therapy of strontium-substituted bioglass for soft tissue wound-healing: Responses to oxidative stress in ovariectomised rats
}

La thérapie biologique de verre bioactif substitué au strontium pour lacicatrisation de tissu mous : les réponses au stress oxydatif chez la rateovariectomisée

S. Jebahia,, b, ,d, H. Oudadessea,e, N. Jardakd,e,I. Khayata, H. Keskesd,e, A. Khabire, T. Rebaid,H. El Fekic,e, A. El Feki

aUniversity of Rennes-1, UMR CNRS 6226, campus de Beaulieu, 263, avenue du Général-Leclerc, 35042 Rennes, France

bAnimal Ecophysiology Laboratory, Sfax Faculty of Science, Department of Life Sciences,Sfax, Tunisia

cScience Materials and Environment laboratory, Sfax Faculty of Science, Sfax, Tunisia

dHistology and Orthopaedic and Traumatology laboratory, Sfax Faculty of Medicine, Sfax,TunisiaeAnatomy and Cytology Laboratory, CHU Habib Bourguiba, 3029 Sfax, Tunisia

Corresponding author.E-mail address: jbahisamira@yahoo.fr. 


\section{Summary}

New synthetic biomaterials are constantly being developed for wound repair and regeneration. Bioactive glasses (BG) containing strontium have shown successful applicationsin tissue engineering account of their biocompatibility and the positive biological effects after implantation. This study aimed to assess whether BG-Sr was accepted by the host tissue and to characterize oxidative stress biomarker and antioxidant enzyme profiles during muscle and skin healing. Wistar rats were divided into five groups (six animals per group): the group (I) was used as negative control (T), after ovariectomy, groups II, III, IV and V were used respectively as positive control (OVX), implanted tissue with BG (OVX-BG), BG$\mathrm{Sr}$ (OVX-BG-Sr) and presentedempty defects (OVX-NI). Soft tissues surrounding biomaterials were used to estimate superox-ide dismutase (SOD), catalase (CAT), glutathione peroxidase (GPx) and malondialdehyde (MDA) concentration. Our results show that 60 days after operation, treatment of rats with BG-Sr significantly increased MDA concentration and caused an increase of SOD, CAT and GPx activities in both skin and muscular tissues. BG-Sr revealed maturation of myotubes followed anormal appearance of muscle regenerated with high density and mature capillary vessels. High wound recovery with complete reepithelialization and regeneration of skin was observed. The results demonstrate that the protective action against reactive oxygen species (ROS) was clearly observed in soft tissue surrounding BG-Sr. Moreover, the potential use of BG-Sr rapidly restores the wound skin and muscle structural and functional properties. The BG advantages such as ion release might make BG-Sr an effective biomaterial choice for antioxidative activity.

Oxidative stress; Bioglass; Strontium; Soft tissue regeneration; Antioxidative activity 


\section{Résumé}

Des nouveaux biomatériaux sont synthétisés pour la régénération de tissus. Les verres bioactifs (BG) contenant du strontium ont montré des effets biologiques positifs au niveau de l'ingénierie tissulaire. Cette étude vise à évaluer la tolérance de BG par le tissu hôte et de caractériser les biomarqueurs du stress oxydatif et les profils des enzymes antioxydantes au cours de la guérison des muscles et de la peau. Des rates Wistar ont été divisées en cinq groupes(six rates par groupe): le groupe (I) était utilisé comme témoin négatif (T), après une ovariec-tomie, les groupes II, III, IV et V étaient respectivement utilisés comme contrôle positif (OVX),tissu implanté avec BG (OVX-BG), BG-Sr (OVX-BG-Sr) et présenté des défauts vides (OVX-NI).Les tissus environnants les biomatériaux ont été utilisées pour estimer la superoxyde dismutase (SOD), la catalase (CAT), glutathion peroxydase (GPx) et le malondialdéhyde (MDA). Nos résultats montrent que 60 jours après l'opération, le traitement des rates avec BG-Sr a entraînéune augmentation de malondialdéhyde (MDA) et les activités de SOD, CAT et GPx au niveau de muscle et de la peau. Le BG-Sr a révélé au niveau de muscle une maturation et une vascular-isation de tissu. Au niveau de la peau, une complète réépithélialisation a été observée. Les résultats démontrent des effets protecteurs de BG-Sr contre les espèces réactives de l'oxygène(ERO). En outre, son utilisation permet de rétablir les propriétés structurelles et fonctionnelles musculaires et la régénération de la peau. La relarguage des ions par le BG pourrait faire un choix efficace pour l'activité antioxydante.

\section{MOTS CLÉS}

Le stress oxydatif; Verre bioactif ; Strontium ;La régénération des tissus mous; Des activités antioxydantes 


\section{Introduction}

The beneficial effect of strontium $(\mathrm{Sr})$ as a potential antios-teoporotic factor at a low dose has been well documented [1]. Current studies have taken the benefits of $\mathrm{Sr}$ on bone regeneration by incorporating it into various bone graft bio-materials [2]. Among these biomaterials, bioactive glasses (BG) have been widely used thanks to their biological properties. In fact, they have the ability to bond to hard tissue and to form a carbonated hydroxyapatite layer (HCA) when exposed to a biological fluid [3]. Furthermore, the ionic dissolution products from bioglass (e.g. Si, Ca, and P) stimulate expression of several osteoblastic cell genes [4]. The substitution of $\mathrm{Sr}$ with bioglass enhances bone healing; moreover, it is believed to favourably affect the cell proliferation and differentiation and to develop both osteogenesis and angiogenesis properties. Interestingly, many previous studies have indicated that the release of degradation products from these materials affects the tissue responses. Within these responses, reactive oxygen species (ROS) are generated by activated phagocytes. Current studies have demonstrated that ROS could exert positive as well as negative effects in many tissues [5]. As regards the positive effects, ROS play an important role after injury when adequate amounts of reactive ions or molecules including hydrogen peroxide $(\mathrm{H} 2 \mathrm{O} 2)$, superoxide $(\mathrm{O} 2-)$, hydroxyl radicals $(\mathrm{OH} \cdot)$ are produced by damaged endothelial and smooth muscle cells. Thus, ROS contribute to angiogenic signalling [6]. The negative ROS effects consist in the contribution to the disease pathology and complication [7]. After implantation, the skeletal muscles surrounding the biomaterials are affected by different particle sizes and morphologies. They exhibited differences in their behavioral, physiological, and cellular responses. The effects of implants on bony tissue have been investigated [8]. However, only few studies have directly addressed the effect upon the adjacent skeletal muscle and skin tissue. Our hypothesis is that Sr may contribute to the ROS imbalance control during hormonal insufficiency in the soft tissue surrounding BG-Sr. In the present study, we aimed to investigate the antioxidant activity of BG with $0.1 \mathrm{wt} \% \mathrm{Sr}$. The particle size ranged between 40 and $63 \mu \mathrm{m}$ against the free radicals induced by estrogen deficiency and correlated with the tissue biocompatibility during the osteoporosis development.

\section{Material and methods}

\section{Bioactive glass synthesis}

The first material studied was pure 46S6 possessing com-positions close to that of Hench's 45S5 [9] and used as a reference to validate our experimental procedure. Then, $0.1 \%$ wt of $\mathrm{Sr}$ 
was introduced into the 46S6 bio-glass. Appropriate amounts of calcium metasilicate, sodiummetasilicate, sodium metaphosphate, and magnesium oxide were weighed and mixed for 45 min using a planetary mixer. The powdered mixture was heated in a platinum crucible at $1300^{\circ} \mathrm{C}$ for $3 \mathrm{~h}$. The molten material was then poured into preheated brass molds to form cylinders of $13 \mathrm{~mm}$ in diameter and $10 \mathrm{~mm}$ in height. The prepared samples were annealed for $4 \mathrm{~h}$ at the appropriate temperature, corresponding to the phase transition temperature of the glass composition (about $560^{\circ} \mathrm{C}$ ), in a regulated muffle furnace, which was left to cool to room temperature at a rate of $1{ }^{\circ} \mathrm{C}$ min -1 . After elaboration, the powder particles sized between $40-63 \mu \mathrm{m}$ were compressed in a perfectly isostatic manner. The prepared implants were sterilized by $\gamma$-irradiation from a 60Co Source gamma irradiation at a dose of $25 \mathrm{~Gy}$ (Theratron external beam teletherapy, Equinox, Ottawa, ON, Canada) using standard procedures for medical devices.

\section{Animal model}

Female Wistar rats (16-19 weeks of age), obtained from the central pharmacy, Tunisia, and bred in the central animal house were used in this study. The rats were acclimatized to their new environment for 7 days before the beginning of the study. The animals were fed on a pellet diet (Sicco, Sfax,Tunisia) and water ad libitum. All the animals were kept under climate-controlled conditions $\left(25^{\circ} \mathrm{C} ; 55 \%\right.$ humidity; $12 \mathrm{~h}$ of light alternating with $12 \mathrm{~h}$ of darkness). The handling of the animals was approved by the Tunisian ethical commit-tee for the care and use of laboratory animals. All rats were randomly divided into five groups (six animals per group): the first group (I) was used as negative control (T). Sixty days after bilateral ovariectomy, groups II, III, IV and V were used respectively as positive control (OVX), implanted tis-sues with BG (OVX-BG), BG-Sr (OVX-BG-Sr) and the last one presented empty defects (OVX-NI).Surgical and postoperative protocol. All surgical interventions were performed under general anaesthesia in aseptic conditions. Anaesthesia was induced with xylazine (7 to $10 \mathrm{mg} / \mathrm{kg}$ (i.P) Rompun ${ }^{\circledR} 2 \%$ ) and ketamine (70 to $100 \mathrm{mg} / \mathrm{kg}$ (i.m) Imalgene $\left.{ }^{\circledR}\right)$ depending on the bodyweight. Animals were shaved and prepared for surgery. BG and BG-Sr in a similar disc form were placed into 1-cm muscular and subcutaneous pouches in ovariectomised rats. On days 4, 7, 15, 30 and 60 after implant insertion, all rats were sacrificed and specimens were harvested for biological evaluation. 


\section{Tissue preparation}

The muscular and skin tissues surrounding the biomaterials were carefully removed, cleaned, dried and processed for antioxidant enzyme analysis. The homogenates were pre-pared on ice in the ratio $2 \mathrm{~g}$ tissue for $8 \mathrm{ml}$ of phosphate buffer saline, centrifuged at $9000 \mathrm{rpm}$ for $15 \mathrm{~min}$ at $4 \circ \mathrm{C}$ and frozen at $-70 \circ \mathrm{C}$ until analysis.

\section{Oxidative stress measurements}

The lipid peroxidation in the muscular and skin tissues of control and all treated animal groups was measured by the quantification of thiobarbituric acid-reactive substances (TBARS) determined by the method of Buege and Aust [10].The activity of superoxide dismutase (SOD) was assayed by the spectrophotometric method of Marklund and Marklund [11]. The glutathione peroxidase (GPx) activity was measured by the method described by Pagila and Valentine [12]. Catalase (CAT) was assayed calorimetrically at $240 \mathrm{~nm}$ and expressed as moles of $\mathrm{H}_{2} \mathrm{O}_{2}$ consumed per minute per milligram of protein, as described by Aebi [13]. The level of total protein was determined by the method of Lowry et al.using bovine serum albumin as the standard at $660 \mathrm{~nm}[14]$.

\section{Histological study}

Both muscular and skin tissue of control and all treated groups were fixed in $10 \%$ formalin and embedded in paraffin. Thereafter, 4-5 $\mu \mathrm{m}$ paraffin sections were stained with hematoxylin — eosin and subjected to microscopic examination.

\section{Statistical analysis}

The statistical analysis of the data was made using Student'st test. All values were expressed as means \pm SE. Differences are considered significant at the $95 \%$ confidence level $(\mathrm{P}<0.05)$.

\section{Results}

\section{Antioxidant status during skeletal muscle healing}

As illustrated in Fig. 1a-c, the data on the SOD, CAT, and GPx activities in the skeletal muscle of OVX rats showed a highly significant decrease when compared to those of control rats. Also ovariectomy significantly elevated the malondialdehyde (MDA) levels ( $\mathrm{P}<0.001)$ (Fig. 2). The results showed that after 4 and 7 days, the CAT, SOD and GPx activities in OVX-BG-Sr, OVX-BG groups decreased significantly $(\mathrm{P}<0.001)$ as compared to those of 
OVX rats. In addition, an enhancement increase in MDA levels $(\mathrm{P}<0.001)$ was observed. The results clarified that implantation of both BG-Sr and BG showed a pronounced release in the free radical content. These activities were more pronounced than those of OVX-NI group. However, 15 days after operation, the SOD, CAT and GPx activities showed a significant enhancement and the maximum was administered after 60 days. In fact, the SOD, CAT and GPx activities in OVX-BG were increased by $12 \%, 22.5 \%$ and $12 \%$, respectively when compared to those of OVX rats. Besides, we noted a decrease in MDA levels by $43.4 \%$. Similarly, a significant increase by $16 \%, 26 \%$ and $19.5 \%$ was shown in OVX-BG-Sr rats as compared to those of OVX groups. We also observed a decrease of MDA by 44.5\%.Antioxidant status during cutaneous wound healing. The data on the SOD, CAT, and GPx activities in the cutaneous tissue of OVX rats showed a significant decrease when compared to those of controls rats (Fig. 3a-c). More-over, ovariectomy significantly elevated the MDA levels.

\section{Muscle histopathology}

After 4 days of BG and BG-Sr implantation, we noted the presence of numerous necrotic myofibrils with different caliber sizes. They were mildly swollen. Their cytoplasm was paler than that of control and had a homogenized appearance without striations (Fig. 5a-c). Moreover, we noted that leukocyte infiltration was more accentuated in BG than that of BGSr- treated rat muscles (Fig. 5d, e). This dam-age paralleled the significant enhancements of MDA level detected in skeletal muscle tissue implanted with BG and BG-Sr in the same period of 4 days. After 7 days, the various events typical of regeneration were observed in BG treated muscle. The BG individual myofibers had a thin pericellular endomysium with groups of myofibers surrounded by a thicker perimysium than those of BG-Sr treated groups (Fig. 5f, g). The BG treated rat myofibers were smaller in size than those of BG-Sr treated rats, but like the normal muscle, they were polygonal and possessed peripheral nuclei.

After 15 days, the myofiber size in BG-Sr group matched that of normal muscle and was considerably large. BG-Sr regenerating regenerate muscle exhibited three morphologically distinguishable zones: an outer zone of original surviving myofibers, a middle myogenic zone composed of proliferated myoblasts and small myotubes, and an inner zone of degenerated myofibers (Fig. 5h). Many nerves and blood vessels restoration between fiber muscle in BG$\mathrm{Sr}$ and BG treated rat muscles was seen (Fig. 5i, j). After 60 days, the entire muscle was filled with polygonal myofibers. Moreover, we noted the uniformity of muscle fibers appearing in 
both BG and BG-Sr with longitudinal striations. This regeneration paralleled the significant decrease of MDA level detected in skeletal muscle tissue surrounding BG and BG-Sr in the same period (Fig. 3k, 1).

\section{Skin histopathology}

The histological examination revealed that skin of BG-Sr and BG treated ovariectomised rats showed inflammatory pat-terns on day 4 (Fig. 6a, b). The inflammatory cells were particularly abundant in the dermal compartment. However, neither BG-Sr nor BG treated group induced prolonged or exaggerated inflammatory responses. In fact, the inflammatory cells and microvessels in the regenerated tissues were gradually degraded and substituted by collagen fibers (Fig. 6c, d). After 15 days, the histological examination revealed that the growth of epidermal cells was retarded in BG treated group and epithelization was limited in the NI group in comparison with that of BG-Sr treated group. The restoration kinetics of cellular bases was significantly enhanced in BG-Sr treated group. The wound in group BG-Sr site was completely covered with epithelial cells and the thickness of the epidermis was comparable to that of a nor-mal rat (Fig. 6e). After 8 weeks, the histological sections of BG-Sr skin treated group exhibited neovascularisation, manymature hair follicles, sebaceous gland cells and completere-epithelialization (Fig. $6 \mathrm{f}-\mathrm{h}$ ).

\section{Discussion}

Bioglass is considered as a promising material in the con-text of tissue engineering applications. The ionic dissolution products from bioglass in vivo are key to understanding the behaviour of these materials. During biomaterial/tissue interaction, there is a possible imbalance in the oxidative status contributing to the complication of graft substitutes and tissue damages. When biomaterials are implanted, a series of biological events occur $[15,16]$. Proteins adsorb on the biomaterial surface almost immediately. Moreover, inflammation leads to the chemo-attraction of activated phagocytes. The phagocytic activities of neutrophils and macrophages are an appropriate source that release pro-inflammatory cytokines, cytotoxic proteases, and free radicals, including reactive oxygen [17]. Here, as well as in the skin, the skeletal muscle tissues surrounding BG-Sr and BG indicated a significant rise in MDA concentration level and reduction in SOD, CAT, GPx activities during the first week in ovariectomised rats. These activities were very limited in ovariectomised rats. In fact, estrogen is a strong antioxidant having the ability to diminish cell membrane disruption. Moreover, estrogen showed to prevent the decrease in skin collagen in post-menopausal 
women receiving hormone replacement therapy [17]. Hence, the decrease of the antioxidative activities in all treated rats can be partially explained by the fact that after ovariectomy, circulating estrogen levels is dropped and their positive effects on skeletal muscle thus decrease in all ovariectomised rats. However, the pronounced activity in the BG-Sr and BG treated group can be explained by the fact that the degradation products of matrix bioglass stimulate inflammatory reactions and leukocyte invasion that can be responsible for further collateral damage to healthy tissue. Current findings show that the reactions through neutrophils are capable of direct lysis of muscle cell membranes through a superoxide-dependent mechanism. Superoxide can be rapidly removed by reaction with other free radicals or by conversion to hydrogen peroxide by SOD [18].Hydrogen peroxide is a stronger oxidant than superoxide and has the capacity to peroxidize lipids and damage cell membranes [19]. Hydrogen peroxide can also be converted to more highly reactive free radicals including hydroxyl radicals. Therefore, modified muscle and skin tissue used during and after surgical procedures can affect the level of SOD expression [20]. In general, the persistent formation of ROS can overcome antioxidant defenses, and thus result in the oxidative stress imbalance. In this study, after 8 weeks, BG-Sr materials with $0.1 \mathrm{wt} \% \mathrm{Sr}$ treated muscular group showed a $16 \%, 26 \%$ and $19.5 \%$ increase in SOD, CAT and GPx activities and decrease of MDA by $44.5 \%$ compared with those of other groups. Moreover, the skin showed $31.1 \%$, 26\% and $45.5 \%$ increase in SOD, CAT, GPx activities and a decrease in MDA level by 44,6\% as compared with those of other groups. A recent study showed that with biocompatible materials, an early resolution of the acute and chronic inflammatory responses occurred with the chronic inflammatory response usually lasting no longer than two weeks. Moreover, a current study shows a strong relationship between free radicals and inflammatory response. Therefore, free radicals could indeed be a useful tool in tissue engineering. In fact, musclederived free radicals can reduce neutrophil mediated lysis of muscle cells and decreases superoxide concentration in the media [21]. This protective effect could occur by free radicals scavenging of superoxide to prevent its conversion to a more cytotoxic oxidant [22]. Muscle and skin-derived free radicals may also serve to protect tissues from dam-age by inflammatory cells by inhibiting the expression of adhesion molecules that are necessary for leukocyte interactions with the vascular endothelium [23]. On the other hand, the imbalance in the oxidative situation can be associated with biomaterials properties such as surface chemistry, size and shape. These properties are responsible for modifying the inflammatory intensity, time duration and wound healing processes. Recently, there has been a study regarding data on $\mathrm{SiO} 2$ nanoparticle-induced oxidative stress and pro-inflammatory responses 
in rodent and in different types of cultured mammalian cell lines [24]. In our study, bioglasses are largely the result of the uniformity of granules within a narrow size range from 40 to $63 \mathrm{~m}$. It has been shown that when the particle size is lower than $200 \mu \mathrm{m}$, biomaterial resorption occurs too rapidly [25]. Conversely, when the particle size is greater than $400 \mu \mathrm{m}$, the particles remain unreacted and are not resorbed, thus impeding the formation of new bone tissues throughout the particle-bone matrix [26]. The results suggest that ROS generated from BG-Sr biomaterial may be involved in creating appropriate conditions for healing tissues and affect positively angiogenesis, remodeling and proliferation in both skeletal muscle and skin tissues. In fact, a recent study has been per-formed to determine the ability of strontium-doped calcium polyphosphate (SCPP) to induce angiogenesis via researching its effect on the mRNA expressions and protein secretion of VEGF and bFGF in/from cultured cells [27]. Nowadays, there is a broad consensus that for most tissues and organs, vascularization is the key process for regeneration. It represents an attractive target cell source for therapeutic neovascularization and revascularization, which can provide nutrients for tissue regeneration, and create suitable conditions for tissue growth [28]. Sr affects angiogenesis, which is imperative in wound healing to maintain the cell activity for tissue repair. Here, in both muscular and skin tissues, the tissue healing as a function of implant time shows an enhanced angiogenesis. Accordingly to these results, bioglass containing $0.1 \%$ dose of strontium serve as a potential biomaterial for stimulating angiogenesis and tissue regeneration in the context of tissue engineering applications.

\section{Conclusion}

The present study indicated significant alterations in antioxidant profile during muscular and cutaneous wound healing in ovariectomised treated rats. All these alterations were observed mostly during the first week of healing. After 8 weeks of treatment, this study demonstrated that soft tissue surrounding BG materials with $0.1 \mathrm{wt} \% \mathrm{Sr}$ had significantly decreased MDA concentration level and increased the activities of SOD, CAT and GPx. BG-Sr used as a substitute graft might be an effective strategy for soft tissue healing therapies as it might contribute to the control of ROS imbalance during hormonal insufficiency.

\section{Disclosure of interest}

The authors declare that they have no conflicts of interest concerning this article. 


\section{References}

[1] Marie PJ, Hott M, Modrowski D, De Pollak C, Guillemain J,Deloffre P, et al. An uncoupling agent containing strontium pre-vents bone loss by depressing bone-resorption and maintainingbone-formation in estrogen-deficient rats. J Bone Miner Res1993;8:607—15.

[2] Park JW, Kim HK, Kim YJ, Jang JH, Song H, Hanawa T. Osteoblastresponse and osseointegration of a Ti-6Al-4V alloy implantincorporating strontium. Acta Biomater 2010;6:2843-51.

[3] Oudadesse H, Dietrich E, Gal YL, Pellen P, Bureau B, MostafaAA, et al. Apatite forming ability and cytocompatibility of pureand Zn-doped bioactive glasses. Biomed Mater 2011;6:035006.

[4] Isaac J, Nohra J, Lao J, Jallot E, Nedelec JM, Berda LA,et al. Effects of strontium-doped bioactive glass on thedifferentiation of cultured osteogenic cells. Eur Cell Mater2011;8(21):130—43.

[5] Estacio MAC, Tsukamura H, de Luna MCT, Maeda KI. Neural path-way of estrogen receptor á expression during stress-inducedsuppression of luteinizing hormone secretion. Philipp J Vet Med2009;46:61-72.

[6] Ushio-Fukai M, Alexander RW. Reactive oxygen species as medi-ators of angiogenesis signaling: role of NAD (P)H oxidase. MolCell Biochem 2004;64:85—97.

[7] Morakinyo AO, Iranloye BO, Daramola AO, Adegoke OA. Antifer-tility effect of calcium channel blockers on male rats: associa-tion with oxidative stress. Adv Med Sci 2011;1(56):95-105.

[8] Jebahi S, Oudadesse H, El Feki H, Rebai T, Keskes H, PascalP, et al. Antioxidative/oxidative effects of strontium-dopedbioactive glass as bone graft, in vivo assays in castrated rats.J Appl Biomed 2012;10:195-209.

[9] Hench LL. Bioceramics. J Am Ceram Soc 1998;81:1705-28.

[10] Buege JA, Aust SD. Microsomal lipid peroxidation. MethodsEnzymol 1984;105:30210 . 
[11] Marklund S, Marklund G. Involvement of the superoxide anionradical in the autoxidation of pyrogallol and convenient assayfor superoxide dismutase. Eur J Biochem 1975;47:46974.

[12] Pagila DE, Valentine WN. Studies on the quantitative and quali-tative characterization of erythrocyte glutathione peroxidase.J Lab Clin Med 1967;70:158 - 69.

[13] Aebi H. Catalase in vitro. Methods Enzymol 1984;105:121-6.[14] Lowry OH, Rosebrough NJ, Farr AL, Randall RJ. Proteinmeasurement with Folin phenol reagent. J Biol Chem1951;193:265-75.

[15] Jebahi S, Nsiri R, Boujbiha M, Bouroga E, Rebai T, Keskes H,et al. The impact of orthopedic device associated with carbon-ated hydroxyapatite on the oxidative balance: experimentalstudy of bone healing rabbit model. Eur J Orthop Surg Trauma-tol 2012, http://dx.doi.org/10.1007/s00590-012-1087-8 [Epubahead of print].

[16] Wang LS, Wang XJ, Wang WJ, Yan YG, Yao NZ, Wang XD, et al.Design, biomechanical study, and clinical application of a newpterygo-shaped titanium mesh cage. Eur J Orthop Surg Trau-matol 2012;22:111-7.

[17] Anderson JM, Rodriguez A, Chang DT. Foreign body reaction tobiomaterials. Semin Immunol 2008;20:86-100.

[18] Shah MG, Maibach HI. Estrogen and skin. Am J Clin Dermatol2001;2:143—50.

[19] Fukai T, Ushio-Fukai M. Superoxide dismutases: role in redoxsignaling, vascular function, and diseases. Antioxid Redox Sig-nal 2011;15:1583 - 606.

[20] Aizzat O, Yap SW, Sopiah H, Madiha MM, Hazreen M, ShailahA, et al. Modulation of oxidative stress by Chlorella vulgarisin streptozotocin (STZ) induced diabetic SpragueDawley rats.Adv Med Sci 2010;55:281—8.

[21] Rubanyi GM, Ho EH, Cantor EH, Lumma WC, Botelho LH. Cyto-protective function of nitric oxide: inactivation of superoxideradicals produced by human leukocytes. Biochem Biophys ResCommun 1991;31:1392—7.

[22] Tidball JG. Inflammatory processes in muscle injury and repair.Am J Physiol Regul Integr Comp Physiol 2005;288:345-53. 
[23] Clancy RM, Leszczynska-Piziak J, Abramson SB. Nitric oxide, anendothelial cell relaxation factor, inhibits neutrophil superox-ide anion production via a direct action on the NADPH oxidase.J Clin Invest 1992;90:1116-21.

[24] Mohebbi-Fani M, Mirzaei A, Nazifi S, Tabandeh MR. Oxidativestatus and antioxidant enzyme activities in erythrocytes frombreeding and pregnant ewes grazing natural pastures in dryseason. Rev Med Vet 2012;10:454-60.

[25] Gorustovich AA, Sivak MG, Guglielmotti MB. A novel methodol-ogy for imaging new bone formation around bioceramic bonesubstitutes. J Biomed Mater Res A 2007;81:443—5.

[26] Li ZY, Lam WM, Yang C, Xu B, Ni GX, Abbah SA, et al. Chemicalcomposition, crystal size and lattice structural changes afterincorporation of strontium into biomimetic apatite. Biomate-rials 2007;28:1452-60.

[27] Liu F, Zhang X, Yu X, Xu Y, Feng T, Ren D. In vitro studyin stimulating the secretion of angiogenic growth factors ofstrontium-doped calcium polyphosphate for bone tissue engineering. J Mater Sci Mater Med 2011;22:683—92.

[28] Pardue EL, Ibrahim S, Ramamurthi A. Role of hyaluronan inangiogenesis and its utility to angiogenic tissue engineering. Organogenesis 2008;4:203-14. 


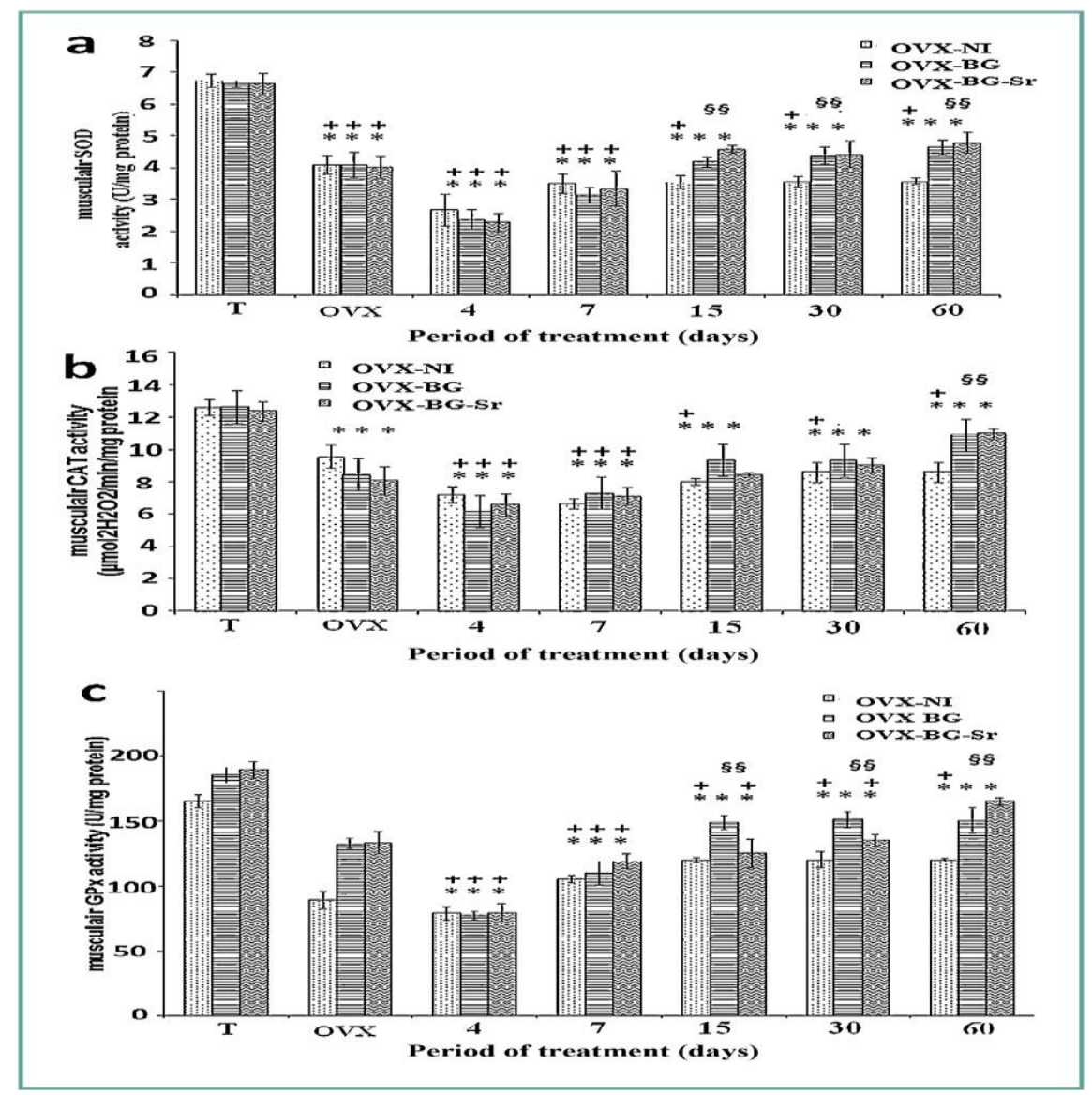

Figure 1. Effects of bioglass (BG) and strontium-doped bioglass(BG-Sr) on superoxide dismutase (SOD) (a), catalase (CAT) (b) and glutathione peroxidase (GPx) (c) activities in muscular tissue ofovariectomised female Wistar rats for 4, 7, 15, 30 and 60 days. Val-ues are given as mean \pm SE. *: significantly less enzymatic activity inthe indicated group than control group (T). +: less enzymatic activ-ity compared to ovariectomised group (OVX). §: higher enzymaticactivity than ovariectomised group with empty defects (OVX-NI).Les effets du bioverre (BG) et du bioverre dopé au strontium (BG-Sr)sur les activités de la superoxyde dismutase (SOD) (a), la catalase (CAT) (b) et la glutathion peroxydase (GPx) (c) au niveau dutissu musculaire des rattes ovariectomisées de souche Wistar ont été évalués durant quatre, sept, 15, 30 et 60 jours. Les valeurs sont exprimées en moyenne \pm SE. * : la valeur de l'activité enzymatique est significativement inférieure dans le groupe indiqué par rapport au témoin $(\mathrm{T}) .+$ : la valeur de l'activité enzymatique est moins significative par rapport au groupe ovariectomisé (OVX).§ : la valeur de l'activité enzymatique est plus élevée que celle du groupe ovariectomisé avec de perte de substance osseuse sans comblement (OVX-NI). 


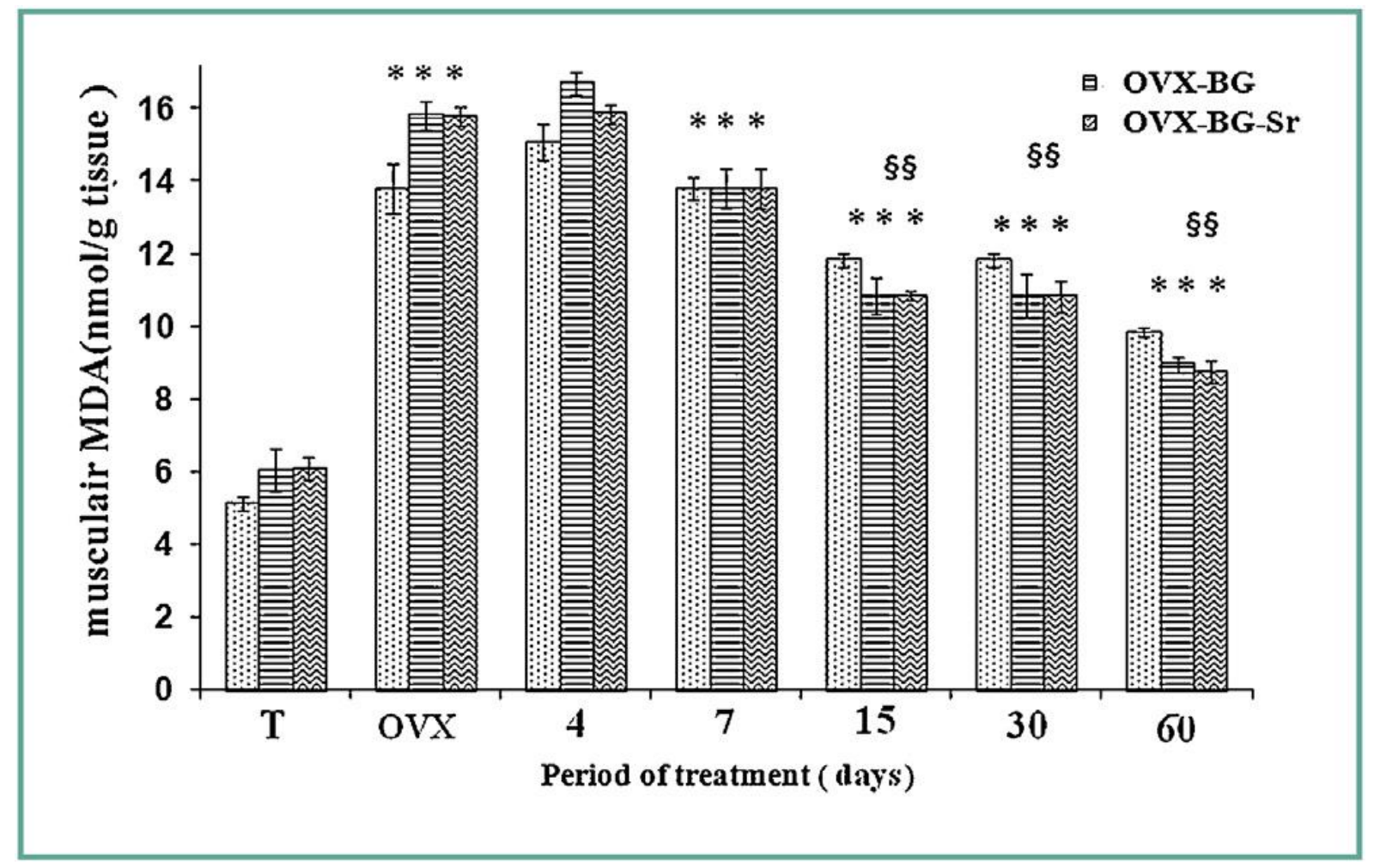

Figure 2. Effects of bioglass (BG) and strontium-doped bioglass (BG-Sr) on malondialdehyde (MDA) level. *: significantly higher levelin the indicated group compared to the control group $(\mathrm{T})$. §: lesserenzymatic activity than ovariectomised group with empty defects(OVXNI). Les effets du bioverre (BG) et du bioverre dopé au strontiumbioverre (BG-Sr) sur le taux de malondialdéhyde (MDA). * : le niveau est significativement plus élevé dans le groupe indiqué par rap-port au groupe témoin $(\mathrm{T}) . \S$ : le niveau de l'activité enzymatiqueest inférieur à celui de groupe ovariectomisé avec de perte desubstance osseuse sans comblement (OVX$\mathrm{NI})$. 

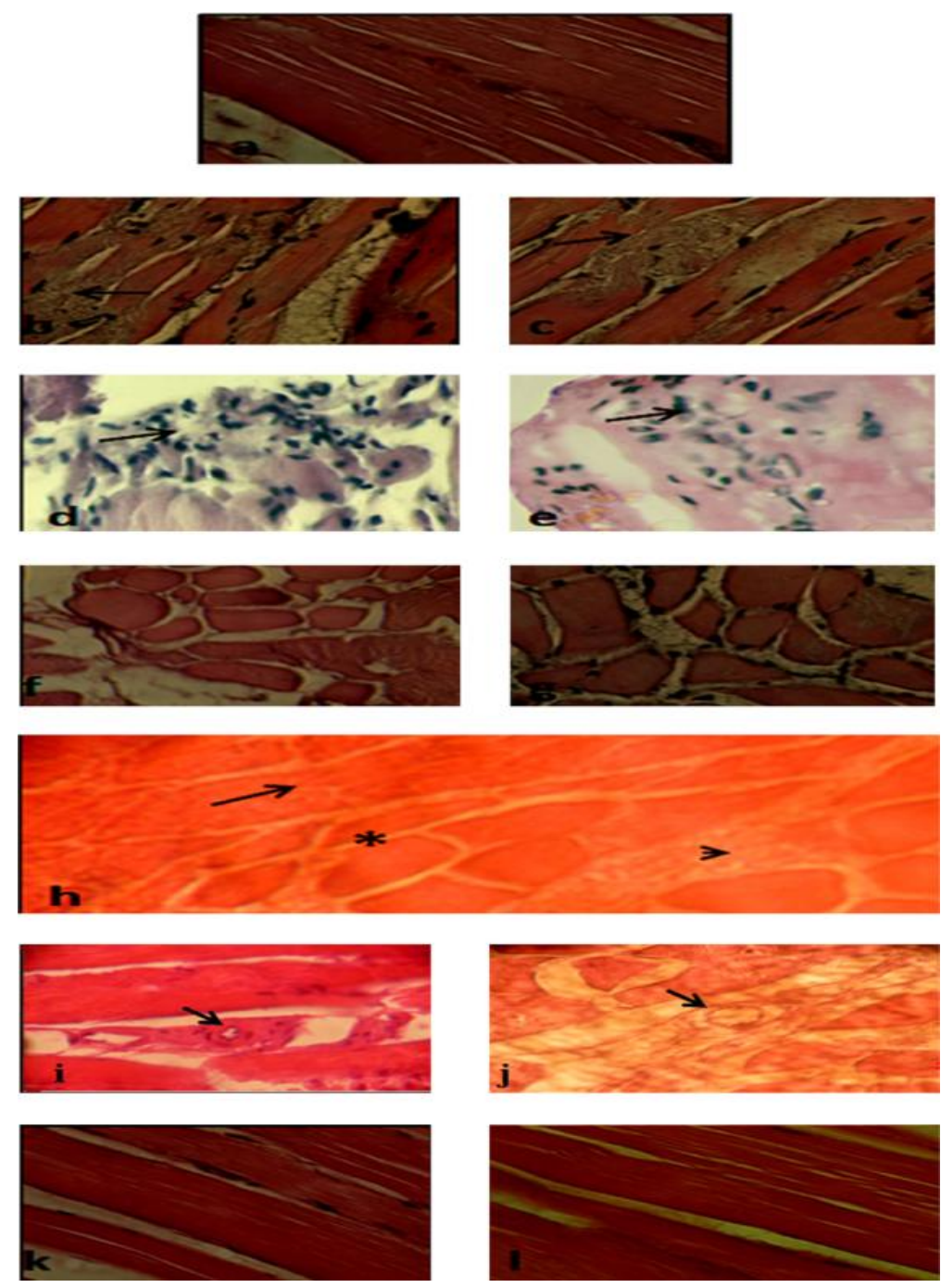

Figure 3. Histological secions of muscular tissue implanted withbioglass (BG) and strontiumdoped bioglass (BG-Sr). Normal mus-cular tissue (a). Necrotic myofibrils in muscular tissue implantedwith BG (b) and with BG-Sr (c), leukocyte infiltration in BG treatedgroup (d) and with BG-Sr (e). A thin pericellular endomysiumi BG (f) with groups of myofibers surrounded by a thicker perimysiumthan those of BG-Sr treated groups (g). Three morphologically distinguishable zones: an outer zone of original surviving myofibers, a middle myogenic zone composed of proliferated myoblasts andsmall myotubes, and an inner zone of degenerated myofibers (h).Nerves (head arrow) and blood vessels (arrow) restoration between fibre muscle in BG treated rat muscles (i) and in BG-Sr treated ratmuscles (j). The entire muscle was filled with polygonal myofibersin BG treated rat muscles (k) and in BG-Sr treated rat muscles (1). Hematoxylin-eosin stain. Des coupes histologiques de tissu musculaire implantées par dubioverre pur (BG) et du bioverre dopé au strontium (BG-Sr), 
tissumusculaire normal (a). Myofibrilles avec des foyers de nécrose auniveau de tissu musculaire implanté par du BG (b) et du BG-Sr (c), graftinfiltration des leucocytes dans le groupe traité par le BG (d) etle BG-Sr (e). Une mince couche de tissu conjonctif, l'endomysiumchez le groupe implanté avec le BG (f), des groupes de fibres mus-culaires entourées d'une couche de périmysium comparé avec lesgroupes traités par les BG-Sr $(\mathrm{g})$. Trois zones morphologiquementdistinctes sont observées : une zone externe de fibres musculaires, une zone centrale composée des myoblastes et des petits myotubes,et une zone intérieure composée de fibres musculaires dégénérées(h). Nerfs (tête de flèche) et des vaisseaux sanguins (flèche) entreles fibres musculaires de rattes traitées par le BG (i) et les rattestraitées par le BG-Sr (j). La totalité de muscle est caractérisée pardes fibres musculaires polygonales chez les rattes traitées par leBG (k) et par le BG-Sr (l). Coloration hématoxyline-éosine. 


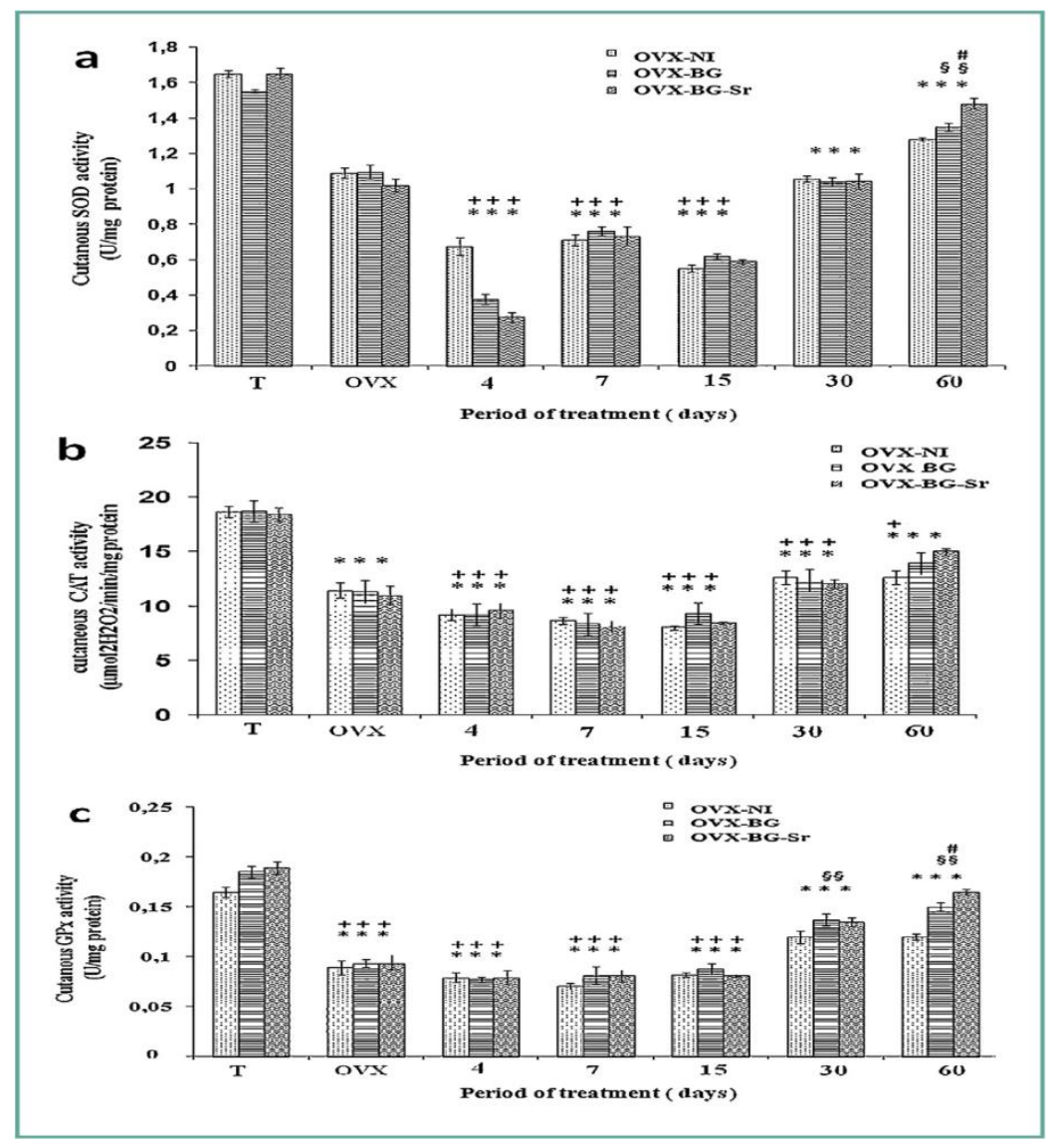

Figure 4. Effects of bioglass (BG) and strontium-doped bioglass (BG-Sr) on superoxide dismutase (SOD) (a), catalase (CAT) (b) andglutathione peroxidase (GPx) (c) activities in cutaneous tissue ofovariectomised female Wistar rats for 4, 7, 15, 30 and 60 days. Values are given as mean \pm SE. *: significantly less enzymatic activ-ity in the indicated group than control group (T). +: compared toovariectomised group (OVX). §: higher than ovariectomised groupwith empty defects (OVX-NI). \#: higher than group implanted with bioglass (OVXBG). Les effets du bioverre (BG) et du bioverre dopé au strontium (BG-Sr)sur les activités de la superoxyde dismutase (SOD) (a), la catalase(CAT) (b) et la glutathion peroxydase (GPx) (c) au niveau du tissucutané des rattes ovariectomisées de souche Wistar ont été évaluésdurant quatre, sept, 15, 30 et 60 jours. Les valeurs sont expriméesen moyenne \pm SE. * : la valeur de l'activité enzymatique est significativement inférieure dans le groupe indiqué par rapport autémoin $(\mathrm{T}) .+$ : la valeur de l'activité enzymatique est significa-tivement inférieure par rapport au groupe ovariectomisé (OVX).§ : la valeur de l'activité enzymatique est plus élevée que celledu groupe ovariectomisé avec de perte de substance osseuse sans comblement (OVX-NI). \# : la valeur est supérieur chez les rattes implantées avec le bioverre pur (OVX$\mathrm{BG})$. 


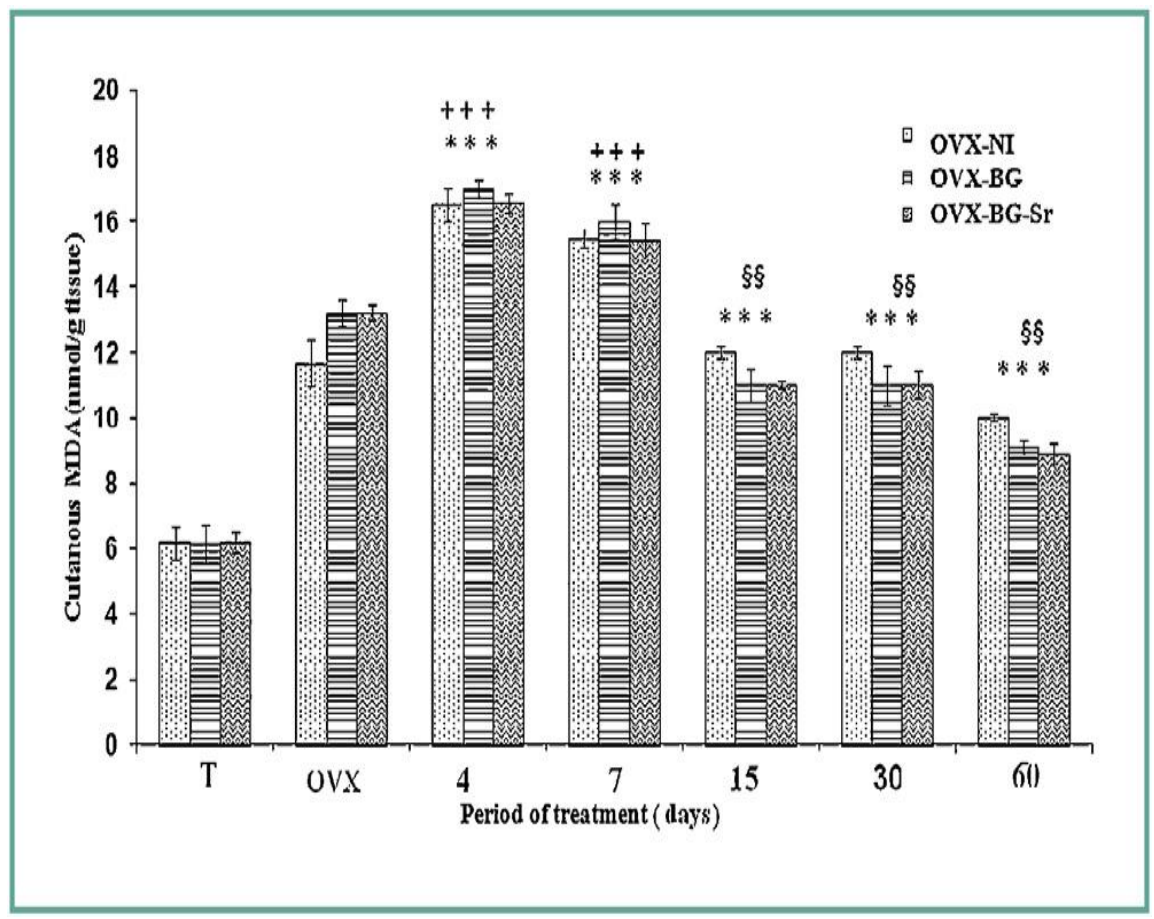

Figure 5. Effects of bioglass (BG) and strontium-doped bioglass(BG-Sr) on malondialdehyde (MDA) level. *: significantly higher levelin the indicated group compared to the control group (T). +: com-pared to ovariectomised group (OVX). §: lesser than ovariectomisedgroup with empty defects (OVX-NI).Les effets du bioverre (BG) et du bioverre dopé au strontium (BG-Sr)sur le taux de malondialdéhyde (MDA). * : le taux est significa-tivement plus élevé dans le groupe indiqué par rapport au groupetémoin $(\mathrm{T}) . \S$ : le taux de l'activité enzymatique est inférieur àcelui de groupe ovariectomisé avec de perte de substance osseusesans comblement (OVX-NI). 

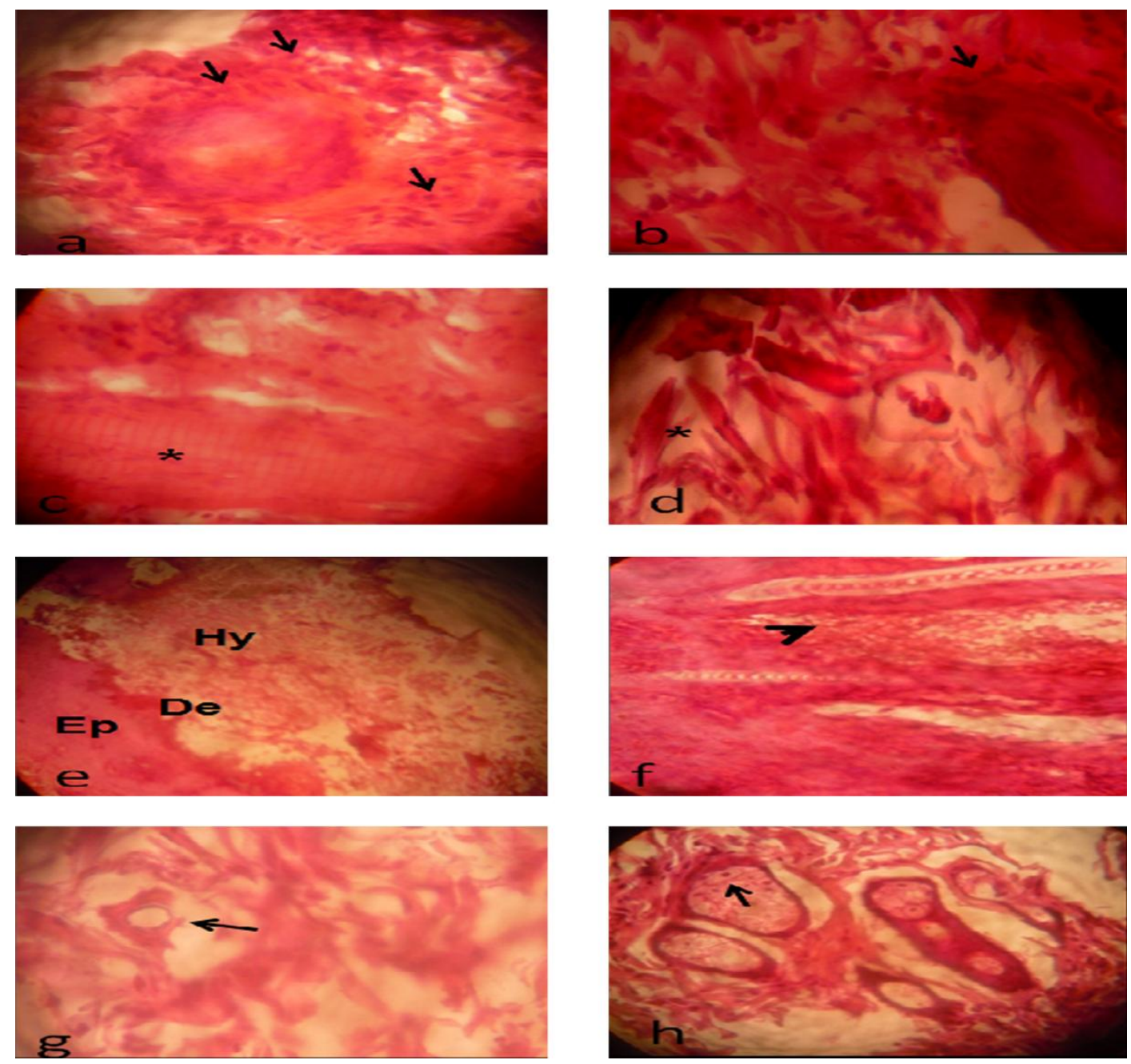

Figure 6. Histological sections of cutaneous tissue implanted with bioglass (BG) and strontium-doped bioglass (BG-Sr). Leukocyte infiltra-tion in BG treated group (a) and BG-Sr (b). Collagen fibers in treated group with BG (c) and with BG-Sr (d). Complete reepithelialization(Ep: epiderm, De: derme, Hy: hypoderm) (e). Many mature hair follicle cells (f) neovascularisation (g), sebaceous gland cells (h) in BG-Srtreated group. Hematoxylineosin stain.Des coupes histologiques du tissu cutané implanté avec le bioverre (BG) et le bioverre dopé au strontium (BG-Sr). L'infiltration de leucocytesdans le groupe traité avec le BG (a) et le BG-Sr (b). Observation des fibres de collagène dans le groupe traité par le BG (c) et avec le BG-Sr(d). La ré-épithélialisation est complète (Ep : épiderme, De : derme, Hy : hypoderm) (e). Observation des cellules matures du follicule pileux(f) des néovascularisation (g), des cellules des glandes sébacées (h) chez le groupe traité avec le BG-Sr. Coloration hématoxyline-éosine. 
